\title{
LIM Domain-Binding Protein 1
}

National Cancer Institute

\section{Source}

National Cancer Institute. LIM Domain-Binding Protein 1. NCI Thesaurus. Code C102887.

LIM domain-binding protein 1 (411 aa, $\sim 47 \mathrm{kDa}$ ) is encoded by the human LDB1 gene.

This protein is involved in transcription factor regulation. 